\title{
„Vše nejlepší, pane prezidente!" Reflexe oslav narozenin hlavy státu v letech 1919-1953 (na přikladu oficiálních pramenů Kanceláře prezidenta republiky)
}

\section{"Happy Birthday, Mr. President!" A Reflection of the President's Birthday Celebrations in 1919-1953 (on the Example of the Official Documents of the Office of the President of the Republic)}

\author{
Aleš Černý / cernya00@ff.jcu.cz \\ Historický ústav, Filozofická fakulta, Jihočeská univerzita v Českých Budějovicích
}

\begin{abstract}
The presented study is trying to analyze the development of the image of the president's birthday celebrations in 1919-1953. The day was one of the most important rituals during the common year. It was also one of the key factors in forming of the collective memory of the Czechoslovak society at that time. That was especially valid in the years when the independent Czechoslovak state was endangered. By comparison, the study is trying to show, how the form of the feast has changed during the reflected period, which was characteristic by dynamic changes of regimes and ideologies.
\end{abstract}

\section{Keywords}

president, feast, ritual, collective memory, Czechoslovakia 1919-1953, celebrations 


\section{Úvod}

V nedávné době u nás vzniklo několik historických prací zabývajících se oficiálním svátkovým kalendářem první Československé republiky. Některé dny, jež se v minulosti pravidelně veřejně oslavovaly, se dnes již nepřipomínají. Příkladem může být oslava narozenin prezidenta republiky. ${ }^{1}$ Jednalo se o festivitu přímo navazující na tradici připomínání narozenin panovníka habsburské monarchie. Po rozpadu Rakousko-Uherska převzal reprezentativní a ceremoniální povinnosti císaře prezident. V tomto ohledu se stala mladá středoevropská republika výjimkou, protože výročí narození hlavy státu je tradiční spíše pro státy, v jejichž čele stojí monarcha. Nicméně, udržení zdání kontinuity československé elity vyhodnotily jako mimořádně důležité. ${ }^{2}$

Přestože první československý představitel úřadu osobně k velkolepě pojatým oslavám zvlášt kladný vztah neměl, dobře si uvědomoval jejich důležitost. ${ }^{3}$ Pro českou a slovenskou část obyvatelstva meziválečného Československa patřil tento den mezi tři nejvýznamnější rituály v průběhu roku. ${ }^{4}$ Narozeniny prezidenta republiky se staly ideální prŕíležitostí k legitimizaci hodnot, na nichž bylo Československo vystaveno. Minimálně do druhé poloviny 40. let totiž republice chyběl výrazný jednotící prvek - národnost, náboženství nebo jazyk. Autorita prezidentského úřadu měla pomoci tento nesoulad překlenout. ${ }^{5}$

Cílem tohoto příspěvku není analyzovat příčiny a možné dopady narušení zmíněné tradice. Výzkum takového formátu by předpokládal existenci několika dílčích studií pro sledované období let 1919-1953, pro něž byla veřejná oslava prezidentových narozenin typická. Ty česká historiografie postrádá. Práce chronologicky postihuje funkční období prvních čtyř československých prezidentů. Tomáš Garrigue Masaryk se o převzetí tradice oslav osobně zasadil a za jeho pobytu v úřadu dosáhla obliba popisované festivity svého vrcholu. Edvard Beneš na něj navázal a charakter svátku byl během jeho funkčních období instrumentalizován. Rozdílné bylo pojetí oslav v rámci obou totalitních ideologií během působení Emila Háchy a Klementa Gottwalda. Toto časté střídání poměrů je vhodné ke vzájemné komparaci a bylo důvodem volby časového vymezení příspěvku.

Pozornost textu je zaměřena na oficiální projevy svátku v podobě, v jaké je prezentovala výkonná moc a Kancelář prezidenta republiky. Na podrobný výzkum regionálních,

1 Zde je nezbytné upřesnění: není pravdou, že by narozeniny prezidenta byly zcela opomenuty. Zmínky v tisku či na internetu je možné dohledat. Nejedná se však již o festivitu slavenou většinou společnosti tak, jak tomu bylo u nás běžné v období, které tento text analyzuje. Oslavy narozenin hlavy státu v masovém měřítku jsou dodnes v některých zemích běžné. Srov. Konigsdag: Netherland celebrates King's Day. The Guardian, 27. 4. 2017; Queen's 90th Birthday: How is it being celebrated? The Daily Telepgraph, 12. 5. 2016; Queen Elizabeth II Celebrates 80th Birthday. The New York Times, 21. 4. 2006; Bandar Seri Begawan Journal. Easy Life in the Shadow of the $\$ 35$ Billion Man. The New York Times, 3. 8. 1995; Hirohito at 80: Focus of Effort to Bridge a Gap. The New York Times, 30. 4. 1981.

2 Kotalík, Matěj: Panovnický kult a kontinuita monarchismu v období proni Československé republiky. In: 19. století v nás. Modely, instituce a reprezentace, které přetrvaly. Ed. M. Řepa. Praha 2008, s. 286-292.

3 Hájková, Dagmar: T. G. Masaryk: Prvorepublikové utvářeni jeho místa v „oficiálni“ paměti. In: Česká pamět. Národ, dějiny a místa paměti. Edd. R. Šustrová - L. Hédlová. Praha 2014, s. 139-140.

4 Tamtéž, s. 167-188. Do zmíněné trojice patřil ještě 28. říjen jako den vzniku československého státu a 2. červenec - výročí bitvy u Zborova.

5 Hájková, D.: T. G. Masaryk, s. 168. 
menšinových a místních aspektů není vzhledem k povolenému rozsahu příspěvku dostatečný prostor. Ani ty však nejsou zcela opomenuty.

Vzájemná komparace oslav narozenin prvních čtyř československých prezidentů může prohloubit znalost o poměrech v tuzemské společnosti ve velmi dynamickém období let 1920-1953. Po roce 1953 k připomínání výročí narození prezidenta republiky sice nadále docházelo, ale oslavy a veřejné manifestace $\mathrm{v}$ masovém měřítku s ním spojené z veřejného prostoru vymizely. Jednalo se o následek revize kultů osobností vrcholných představitelů komunistických stran v Sovětském svazu a Československu. ${ }^{6}$

\section{Metodologie}

To, jaký význam pro společnost rituály a slavnosti mají, neuniklo pozornosti společenských věd. Maurice Halbwachs ve 20. letech 20. století prezentoval myšlenku, že člověk vyjma své osobní (individuální) paměti sdílí s ostatními členy lidské společnosti ještě jeden druh zkušenosti. Označil jej termínem kolektivni pamět. V ní jsou uchovány vzpomínky na specifické historické události, jež se odehrály během jedincova života. ${ }^{7}$ Události jako válka, neúroda nebo právě obřad či svátek často překračují individuální vědomí a výrazně ovlivňují vědomí kolektivní. ${ }^{8}$ Tíha minulosti záměrně vyvolaná zmanipulováním kolektivní paměti podstatné části národa byla klíčová například při prosazování fašistické a nacistické ideologie v Itálii a v Německu. ${ }^{9}$

Existuje více způsobů, pomocí nichž lze na fenomén paměti v dějinách nahlížet. Jejî funkci v dějinách se věnoval britský historik Peter Burke, jehož primárním tématem je lidová kultura. Na základě výsledků svého bádání vymezil pět rozdílných médií, jimiž se kolektivní vědomí přenáší. Jsou to: ústni tradice, paměti a jiné psané památky, hmotné i nehmotné (imaginární) obrazy, jednáni a prostor. Pro zaměření tohoto příspěvku se jako nejdůležitější jeví čtvrté médium - jednání. Míněno je jednání osoby, která se do kolektivního vědomí zaznamenává. Vykonávání jednotlivých obřadů a rituálů u vysoce postavených lidí bylo velmi bedlivě veřejností sledováno. Prezentace jednání přitom nebyla nahodilá, nýbrž se stávala předmětem dlouhého a pečlivého plánování. Tím docházelo k ovlivnění kolektivní paměti obecenstva dle požadovaného záměru. ${ }^{10}$

6 Hájková, Dagmar - Horák, Pavel: Narozeniny prezidenta. In: Sláva republice! Oficiální svátky a oslavy v meziválečném Československu. Edd. D. Hájková - P. Horák - V. Kessler - M. Michela. Praha 2018, s. 178.

7 Halbwachs, Maurice: Kolektivni pamět’. Praha 2009, s. 23, 93-95. Termín sociální skupina je dalším pojmem, jímž se Halbwachs ve své práci zabýval. Sociální skupinou míní například národ, ekonomickou třídu či profesi. Každá z těchto skupin má svoji vlastní kolektivní pamět. Člověk je tedy nositelem několika kolektivních pamětí současně.

8 Tamtéž, s. 101. Na význam rituálů a svátků upozornil rovněž Jan Assman. Označil je za primární organizační formy kolektivní paměti. Assman v podstatě tvrdil, že ritualizovaný akt (normativ) sám o sobě postrádá smysl. Ten je zakódován až v př́iběhu, jenž je s ním spojen (narativ). Každá kultura vlastní takové obsahy. Jejich analýza a chápání je nezbytná pro konstruování národní identity. Srov. Assmann, Jan: Kultura a pamět. Písmo, vzpomínka a politická identita v rozvinutých kulturách starověku. Praha 2001. Chybi stránka.

9 Le Goff, Jacques: Pamět’ a dějiny. Praha 2007, s. 28-36.

10 Burke, Peter: Historie jako sociálni pamět. In: Týž: Variety kulturních dějin. Brno 2006, s. 54-64. 
Ritualizované chování během oslav bylo doprovázeno volbou specifických symbolických prostředků. Jedinec pomocí nich potvrzoval své výjimečné postavení ve společnosti. Autorkou teorie symbolické komunikace je německá historička Barbara Stollberg-Rillingerová. ${ }^{11}$ Symbolika byla nezbytnou součástí oslav lidových svátků. Na důležitosti nabývaly různé předměty a prostory, s nimiž se mohli představitelé sociální skupiny identifikovat a posléze společně nabytou identitu sdílet. ${ }^{12}$

\section{Prameny a literatura}

Při konstrukci předkládaného textu byly využity prameny uložené v Archivu Kanceláře prezidenta republiky. V souborech dokumentů jednotlivých prezidentů lze nalézt zmínky vypovídající o přípravách, průběhu a ohlasech oslav narozenin. Tyto složky jsou součástí ústředního fondu Kancelář prezidenta republiky.

V rámci české i zahraniční historiografie vzniklo několik prací, které se věnují státním svátkům a památným dnům v Československu. Z tuzemské produkce se jedná např́klad o sborník Radky Šustrové a Luby Hédlové s názvem Česká pamět ${ }^{13}$ či publikaci kolektivu autorů pod vedením Milana Hlavačky s titulem Pamět míst, událostí a osobnosti..$^{14}$

Obdobím, kdy u nás oslavy narozenin prezidenta republiky dosahovaly vůbec nejvyšší oblíbenosti a rozsahu, byla éra prezidenství T. G. Masaryka. Zevrubně se podobě oslav jeho narozenin v několika studiích z posledních let věnovala Dagmar Hájková. Tato práce na její výzkum metodologicky i chronologicky navazuje. ${ }^{15} \mathrm{Na}$ Slovensku se k pozici oslav narozenin T. G. Masaryka v oficiálním svátkovém kalendáři meziválečného Československa vyjádřili Zuzana Hajachová ${ }^{16}$ a Dušan Kováč. ${ }^{17}$ Ze zahraničí k tématu přispěla Andrea

11 Klíčové jsou zejména dvě následující práce: Stollberg-Rillinger, Barbara: Symbolische Kommunikation in der Vormoderne. Begriffe - Thesen - Forschungsperspektiven. Zeitschrift für Historische Forschung 31, 2004, č. 4, s. 489-527; Táž: Rituale. Frankfurt am Main 2013.

12 Bůžek, Václav - Dibelka, Jaroslav: Utvářeni identity ve vrstvách paměti. In: Utváření identity ve vrstvách paměti. Edd. V. Bůžek - J. Dibelka. České Budějovice 2011, s. 5-8.

13 Česká pamět. Národ, dějiny a místa paměti. Edd. R. Šustrová - L. Hédlová. Praha 2014.

14 Hlavačka, Milan a kol.: Pamět mist, událostí a osobností. Historie jako identita a manipulace. Praha 2011.

15 Tzn. chápe pojmy a operuje s nimi stejně jako ona a její spoluautoři v publikaci: Sláva republice, s. 18-25. Z prací Hájkové k tématu je dále třeba uvést: Hájková, Dagmar - Wingfield, Nancy: Czechoslovak National Commemorations during the Interwar Period. Tomáš G. Masaryk and the Battle of White Mountain Avenged. Acta Histriae 18, 2010, č. 3, s. 425-452; Hájková, Dagmar: T. G. Masaryk: Prvorepublikové utváření jeho mista v „oficiálni“ paměti. In: Česká pamět, s. 167-188; Hájková, Dagmar - Horák, Pavel: Oslavy narozenin prezidentů v meziválečném Československu. Střed. Časopis pro mezioborová studia střední Evropy 19. a 20. století 7, 2015, č. 2, s. 32-58; Hájková, Dagmar - Horák, Pavel: Narozeniny prezidenta. In: Sláva republice!, s. $137-180$.

16 Hajachová, Zuzana: Oslavy narodenin prezidenta Tomáše Garrigua Masaryka na Slovensku. In: I. Kušniráková a kol.: „Vyjdeme v noci vo fakl'ovom sprievode a rozsvietime svet.“ Integračný a mobilizačný význam slávností v živote spoločnosti. Bratislava 2012, s. 171-185.

17 Kováč, Dušan: Historická pamät’ a ideológia. T. G. Masaryk v slovenskej a českej historickej pamäti. Historické štúdie 51, 2017, s. 161-171. 
Talabér. ${ }^{18}$ Oslavy ani jednoho z Masarykových tří následovníků v odborné literatuře samostatně zachyceny nejsou.

\section{Legislativní vývoj svátku}

Československo bylo po svém vzniku nuceno v mnoha ohledech navázat na habsburskou monarchii. Zákon č. 11/1918 ze dne 28. 10. 1918, který vešel ve známost jako recepčni norma, potvrzoval platnost rakousko-uherského právního řádu. To znamenalo, že i pravidelný pořad svátků se řídil dle dosud zaběhnuté legislativy. ${ }^{19}$

Předlitavské zákonodárství pojem občanského svátku neznalo. Sváteční dny měly v monarchii pouze církevní povahu. Oslava narozenin panovníků v Rakousko-Uhersku tedy nebyla oficiálně součástí systému práva. ${ }^{20}$ Jednalo se o tradici, kterou většina obyvatelstva považovala za samozřejmou součást roku. ${ }^{21}$ Formát oslav nastavený v prvních letech po vzniku Československa byl velmi podobný. Záměrně došlo k volbě modelu, na který bylo obyvatelstvo zvyklé. ${ }^{22}$

V říjnu roku 1919 přijalo Revoluční Národní shromáždění první legislativní úpravu svátkového kalendáře. Zákon č. 555/1919 prohlásil 28. ř́ijen za státní svátek. ${ }^{23}$ Den vzniku samostatného československého státu se tak stal vůbec prvním sekulárním svátkem platným na území českých zemí. ${ }^{24}$

Návrhy nového oficiálního svátkového kalendáře se v prvních letech existence státu v parlamentu střídavě objevovaly. ${ }^{25}$ Diskuze gradovala na jaře roku 1925 . Výsledkem se stal Zákon o svátcích a památných dnech republiky Československé. Národní shromáždění jej přijalo pod pořadovým číslem 65 dne 3. dubna $1925 .{ }^{26}$ Zákon rušil všechna dosavadní nařízení o svátcích přejatých recepční normou. ${ }^{27}$

18 Talabér, Andrea: Commemorative Conundrums: The Creation of National Day Calendars in Interwar Czechoslovakia and Hungary. Bohemia 56, 2016, č. 2, s. 406-436.

19 Čechurová, Jana: Svátkový kalendář ve světle legislativni činnosti. In: Sláva republice!, s. 49.

20 Valeš, Václav: Public Holidays in the Czechoslovak Legal Order (1918-1938). In: Cofola 2008 Conference. Key Points and Ideas. Brno 2008. Dostupné z: https://www.law.muni.cz/sborniky/cofola2008/files/pdf/history/vales_vaclav.pdf, citováno 31. 8. 2019.

21 Význam dne je zřejmý např́klad z textu článku uveřejněného v Pražském denniku v roce 1886: „V Praze vládly $v$ den císařských narozenin černožluté prapory řišskés bašty mariánské a petřinské a městem rozléhala se hned hudba, hned zvonění co důkaz dne neobyčejného... "Srov. Pražský dennik, 20. 8. 1886, s. 1.

22 Hájková, D. - Horák, P.: Narozeniny prezidenta, s. 138-140.

23 Sbírka zákonů a nařizeni státu československého ze dne 25. řína 1919, s. 781.

24 Hájková, D. - Horák, P.: Narozeniny prezidenta, s. 139.

25 Mezi předkladatele patřili i např. Alois Rašín nebo Jan Černý.

26 Talabér, A: Commemorative Conundrums, s. 416. Předkladatelem návrhu zákona byl agrárník Josef Černý, zet̉ Antonína Švehly. Zákon měl své odpůrce mezi německými sociální demokraty, komunisty, lud’áky i některými českými socialisty. Z politické pravice se proti němu vyslovil pouze Viktor Dyk. Srov. Čechurová, J.: Svátkový kalendář, s. 61-62.

27 S jedinou výjimkou. V pátém paragrafu ponechával v platnosti některá ustanovení interkonfesijního zákona z roku 1868. 
Došlo k vymezení tří druhů svátečních dnů - neděle, památné dny, státní svátky. Pro všechny kategorie platil zvláštní režim. Šlo o dodržování tzv. nedělního klidu. Omezena byla pracovní doba, provozní hodiny úřado̊, podniků, škol či hluk. Za památné dny se považovaly: 1. květen, 5. červenec, 6. červenec a 28. září. Speciální statut státního svátku si uchoval 28. ř́ijen podle zmíněného zákona z roku 1919. Zákon zůstal v platnosti až do obsazení okleštěného československého území v březnu 1939. ${ }^{28}$ Ačkoliv se oslavy narozenin prezidenta nezařadily mezi oficiální památné dny, v praxi tak pojímány byly. Úřady se při jejich organizaci nezřídka odvolávaly právě na zákon z roku 1925. Charakter svátku tak lze označit jako polooficiální. ${ }^{29}$

V letech 1939-1945 se pořad svátků na území Protektorátu Čechy a Morava řídil legislativou Velkoněmecké ř́iše. Na rozdíl od bývalého československého práva v ní byly narozeniny jejího nejvyššího představitele kodifikovány. Oslavy narození Vůdce připadaly na 20. duben. ${ }^{30}$

Třetí Československá republika deklarovala návaznost na Československo „před Mnichovem“. Zásada, že státní suverenita nepřestala díky londýnské exilové vládě nikdy existovat, byla uplatněna i v případě kontinuity svátkové legislativy. ${ }^{31}$ Za platný se považoval zákon z roku 1925. Nadále platilo, že se s připomínáním prezidentových narozenin v průběhu roku automaticky počítalo, avšak trvale zakotveny v legislativě nebyly. ${ }^{32}$

V roce 1951 schválilo Národní shromáždění zásadní reformu svátkového práva. Zákon č. 93/1951 ustanovil novou typologii a pořad svátků a významných dnů v průběhu roku. Status prezidentových narozenin ale zákon neupravoval. ${ }^{33}$

\section{Prezident „Osvoboditel” (1919-1935)}

Již v březnu 1919, tedy jen několik měsíců po vzniku nezávislého Československa, si na některých místech republiky obyvatelé skromně připomínali narozeniny „prezidenta Osvoboditele“, Tomáše Garrigua Masaryka. ${ }^{34}$ Avšak teprve k př́ležitosti jeho jubilea

28 Sbirka zákonů a nařizeni státu československého ze dne 15. 4. 1925, s. 433-434. Dle §3 zákona č. 65/1925 mohla veřejná správa k 28. říjnu vydávat nařízení „směřujici $k$ důstojné zevní oslavě tohoto dne“. Neuposlechnutí mohlo být policií trestáno pokutou do 10 tisíc korun či odnětím svobody až po dobu jednoho měsíce.

Hájková, D - Horák, P.: Narozeniny prezidenta, s. 150.

30 Tamtéž, s. 176.

31 Pehr, Michal: Zápas o nové Československo 1939-1946. Praha 2011, s. 141.

32 Hájková, D. - Horák, P.: Narozeniny prezidenta, s. 177.

33 Sbirka zákonů republiky Československé ze dne 6. prosince 1951, s. 250-251. Za státní svátek byl prohlášen pouze 9. květen (osvobození Československa sovětskou armádou). Nová kategorie dnů pracovního klidu zahrnovala: 1. leden, Pondělí velikonoční, 1. květen, 28. ř́ijen, 25. prosinec a 26. prosinec. Do další nové kategorie významných dnů spadaly: 25. únor, 29. srpen (Slovenské národní povstání) a 7. listopad (Velká říjnová socialistická revoluce). Památnými dny zůstaly 5. červenec a 6. červenec. Významné a památné dny na rozdíl od státního svátku a dnů pracovního klidu byly dny pracovními. Zákon byl v průběhu druhé poloviny 20. století několikrát pozměněn. K jeho definitivnímu zrušení však došlo až v roce 2000. Srov. Sbírka zákonů České republiky ze dne 9. 8. 2000 , s. 3526.

34 Ne všechny části republiky vnímaly 7. březen jako datum hodné k oslavě. Miliony československých Němců a Mad’arů neviděly k oslavám pádný důvod. Znamenalo by to slavit narozeniny muže, kvůli němuž se ocitli 
v roce 1920 byly zorganizovány první okázalé oslavy. Svým rozsahem si nezadaly s těmi císařskými. Program dne oslav se stal předmětem několikaměsíčního plánování. Státní zaměstnanci, děti a vojsko se slavností museli zúčastnit..$^{35}$

Centrem oslav byla Praha. Ulice hlavního města zaplnily vlajky a prapory, výkladní skříně obchodů nabízely předměty připomínající vznik nezávislého československého státu. Brzy ráno dne 7. 3. 1920 zaznělo městem 28 dělových salv. ${ }^{36}$

Prezident dopoledne na Hradě uvítal zahraniční diplomaty. Následovala velká audience v trůnním sále, kde mu svá blahopřání vyslovili zástupci Národního shromáždění, vlády, vojska, nejvyšších úřadů, církví, univerzit a vysokých škol. ${ }^{37}$ Prahou pochodovaly vojenské kapely a lampionový průvod. Veliké oblibě se těšily světelné efekty instalované k té př́ležitosti na Petříně. ${ }^{38}$

Ústřední orgány šírily informace potřebné k správnému průběhu oslav pomocí tištěných publikací. Ministerstvo školství a národní osvěty vydalo speciální brožuru. Vyjma směrnic obsahovala shrnutí celoživotní práce prvního prezidenta a několik oslavných básní na jeho počest. ${ }^{39}$

Organizátoři oslav dbali na dostatečné zastoupení symbolů. Místa ceremoniálů byla vyzdobena trikolórou, ${ }^{40}$ státní vlajkou a znaky. Důležitou součástí symboliky byl Masaryk sám. Na významu nabýval i jeho fyzických vzhled. ${ }^{41}$

V očekávání Masarykových pětasedmdesátých narozenin vydalo Ministerstvo školství a národní osvěty novou publikaci, která měla zaručit řádný průběh oslav. ${ }^{42}$ Návrhy programů slavnostního dne v ní byly rozděleny do tří kategorií podle velikosti sídla (menší obce a školy, venkovská města, velká města). Nezapomenulo se na soupis vhodných

ve státě, s nímž neměli nic společného. Svátek ignorovali také komunisté. Odpůrci oslav měli prakticky jen dvě možnosti. Bud' svátek pomíjet, nebo otevřeně proklamovat svůj odpor k němu. Zpravidla volili první variantu. Nejčastější formou odporu proti oslavám se stalo hanobení státních symbolů. Na zdech domů se objevovaly nepatřičné nápisy, byly znehodnocovány vlajky a portréty. Nicméně, přímo v den narozenin k výtržnostem zpravidla nedocházelo. Od roku 1923 přečiny podléhaly zákonu o ochraně republiky. Srov. Hájková, D. - Horák, P.: Narozeniny prezidenta, s. 162, 172-173.

35 Hájková, D.: T. G. Masaryk, s. 172-173. Děti byly součástí většiny oficiálních rituálů. Předávaly květiny, recitovaly básně, zpívaly písně. Obsah vyučování byl podřizován blížícím se oslavám prezidentových narozenin. Psaly se slohové útvary na téma 7. březen, nacvičovaly se divadelní představení a slavnostní akademie. Vojenská přehlídka se stala častým prvkem oslav. Přispěla k tomu jak představa Masaryka jako „velitele legionářů “ během první světové války, tak i normativní ukotvení funkce prezidenta jako nejvyššího představitele ozbrojených sil.

36 Československá republika, 8. 9. 1920, s. 3.

37 Národni politika, 7. 3. 1920, s. 3.

38 Československá republika, 7. 3. 1920, s. 10.

39 Bláha, Arnošt: T. G. Masaryk: Oslavné básně k jeho 70. narozeninám. Slavnosti Masarykovy. Praha 1920. Mezi přispěvatele patřili Viktor Dyk, Rudolf Těsnohlídek či Antonín Sova.

40 K tradiční bílé a červené nově přibyla barva modrá. Stalo se tak zejména kvůli snaze odlišit se od sousedního Polska či Rakouska.

41 Prezident akcentoval monarchistické prvky v souladu s představou panovníka, na kterou byli Češi zvyklí od konce 18. století. Byl štíhlé a atletické postavy. Rád a často jezdil na koni a nechával se na něm zpodobňovat. Srov. Šedivý, Ivan: T. G. Masaryk: zrozen k mýtu. Dějiny a současnost 29, 2007, č. 1, s. 16. 
divadelních představení ${ }^{43}$ a výčet doporučených filmových snímků. ${ }^{44}$ Oslavy narozenin byly autory brožury viděny jako př́ležitost k proklamaci jednoty: „Masaryk jako představitel státu náleži všem a chtěli bychom, aby jeho přiklad v̌̌ech vábil a přitahoval. Př́ jeho oslavách necht' umlknou rozpory stran a osob, necht' jsou společným dílem všech, kteři se k němu hlásí jako $k$ milovanému vưdci národa. "45

Velmi očekávaným bylo Masarykovo jubileum v roce 1930. Celá republika měla oslavit prezidentovy osmdesáté narozeniny velkolepě. Většina novin informovala o životě „prezidenta Osvoboditele“ na titulních stranách. Vycházely ohromné náklady upomínkových předmětů. Noviny po několik týdnů zveřejňovaly poznatky z prezidentova soukromí. Čtenáři se mohli dočíst o Masarykově denním programu, oblíbené četbě či korespondenci s osobnostmi z řad československé inteligence. ${ }^{46}$

Od rána dne 6. března 1930 přijímal Masaryk na Hradě domácí a zahraniční gratulanty. ${ }^{47}$ Následovalo blahopřání zástupců československé armády a slavnostní vojenská přehlídka. Večer strávil Masaryk v Národním divadle. ${ }^{48}$ Oficiality vlastního dne narozenin zahájil Masaryk v prostoru Staré sněmovny na Pražském hradě. Vyslechl tam blahopřání členů obou komor Národního shromáždění, která přednesl předseda poslanecké sněmovny Jan Malypetr. ${ }^{49}$

Ústřední událostí následujícího dne se stal obrovský holdovací průvod Prahou. Ten vyrazil ve tři hodiny odpoledne z Václavského náměstí směrem na Hrad. V jeho čele šel primátor hlavního města Karel Baxa. Následován byl dalšími zástupci městské rady a členy pražských odborových organizací spolu s poslanci a senátory. "Jádro pri̛vodu tvořili Sokolové i Sokolky v krojich ze všech pěti žup Vel. Prahy. Sokolstva bylo vưbec z krojových spolků nejvice. Dále šlo v kroji Orelstvo, hasičstvo, legionáři, střelci, kominíci, řezníci, 'Vltavan', jirchári, Spolek pražských děti 28. pěš. pluku, Pěvecká obec čsl., Podpưrný spolek samostatných slepců, skauti, krojová družina, řmeslné cechy, Baráčnici, české spolky aj. “50

Rozsah oslav, trvajících déle než týden, byl monumentální. Lze souhlasit s tvrzením Dagmar Hájkové, že oslavy Masarykových osmdesátin se staly jednou z klíčových událostí formujících pamět československé společnosti meziválečného období. ${ }^{51}$

43 V seznamu představení pro dospělé dominovala dramata. Za vhodné byl považován Dykův Posel nebo Jiráskův Emigrant. Děti měly zhlédnout zejména vlastenecké hry, např. Pro tatícka presidenta od Jaroslava Průchy či Tajemný dub z pera Čeňka Habarta.

44 T. G. Masaryk: Rukovět’ pořadateli̊m oslav jeho 75. narozenin, s. 100.

45 Tamtéž, s. 99.

46 Hajachová, Z.: Oslavy narodenín, s. 177. Poštovní správa k příležitosti prezidentova jubilea rozhodla o emisi nových známek s Masarykovým portrétem. V den narozenin se pak na hlavních poštovních úřadech razítkovalo speciálním červeným inkoustem. Zájem o tyto artefakty byl enormní.

47 Národní listy, 7. 3. 1930. s. 1-2.

48 Tamtéž, s. 2.

49 Národní listy, 8. 3. 1930, s. 1.

50 Národni politika, 8. 3. 1930, s. 2. Průvod byl údajně tak dlouhý, že když jeho čelo dospělo na Hrad, tak konec teprve vycházel z Václavského náměstí. Celou trasu průvodu lemovaly davy přihlížejících. Policejní sbor držel plnou pohotovost. I přes fakt, že se průvodu zúčastnily nebo mu přihlížely desetitisíce lidí, nebyl údajně zaznamenán ani jediný přestupek proti veřejnému pořádku. 
Vrcholem oslav Masarykova jubilea bylo přijetí zákona č. 22/1930. Ten vešel ve známost jako Lex Masaryk. Jeho text zní: „T. G. Masaryk zasloužil se o stát. Výrok tento budiž na věčnou pamět vtesán do kamene v obou sněmovnách Národního shromáždění. "52 Masaryk současně obdržel od Národního shromáždění dar 20 milionů korun. V době nastupující hospodářské krize se ale tento krok nesetkal s přílišným pochopením veřejnosti. Prezident celý obnos rozdělil mezi charitativní spolky a veřejné instituce, čímž zažehnal možný spor. ${ }^{53}$

Masarykovy 85. narozeniny v roce 1935 měly vyloženě manifestační charakter. ${ }^{54} \mathrm{~V}$ proslovech byl patrný důraz na jednotu a spolupráci.$^{55} \mathrm{~V}$ témže roce se zrodil návrh na prohlášení dne 7. března státním svátkem. Skupina senátorů v čele s Václavem Donátem jej předložila Národnímu shromáždění. U části politiků to vyvolalo rozhořčení. Oponenti se domnívali, že schválení Lex Masaryk v roce 1930 bylo dostatečným krokem k uctění činnosti prvního československého prezidenta. Situaci znovu zachránil sám Masaryk. Předstoupil před senát s přáním, aby se den jeho narozenin státním svátkem nestal. Senát, který návrh již schválil, se rozhodl prosbě vyhovět. ${ }^{56}$

Poválečná třetí republika se hlásila k odkazu meziválečného Československa a jejího zakladatele. Reforma zákona v roce 1946 zařadila 7. březen mezi památné dny. Stal se dnem pracovního volna pro všechny bez výjimky. V roce 1951 došlo k úpravě znovu a 7. březen o statut památného dne přišel. T. G. Masaryk zůstal ještě po nějaký čas součástí veřejného prostoru. Následně došlo k bagatelizaci jeho vlivu na vznik Československa a zařazení jeho osoby mezi představitele „buržoazie“. ${ }^{57}$

\section{Prezident „Budovatel“ (1935-1938)}

Dne 18. 12. 1935 zvolilo Národní shromáždění prezidentem Edvarda Beneše ${ }^{58}$ Bylo zřejmé, že oslavy narozenin prezidenta republiky se od následujícího roku budou odehrávat v jiném termínu. Nicméně, 7. březen jako den narozenin T. G. Masaryka se slavil dále, i když účast státních zaměstnanců již vyžadována nebyla. Datum začalo nově sloužit jako prostor pro manifestaci souhlasu s hodnotami bývalé hlavy státu a ideou jednotného československého národa. ${ }^{59}$ Kontinuitu umocňovala Benešova osobní vazba na T. G. Masaryka.

52 Sbirka zákonů a nařizeni státu československého ze dne 6. 3. 1930, s. 55.

53 Hájková, D.: T. G. Masaryk, s. 175.

54 Hajachová, Z.: Oslavy narodenín, s. 182-185. Masaryk byl v rámci oslav jmenován čestným občanem města Bratislavy.

55 Archiv Kanceláře prezidenta republiky, Hodinka telefonních blahopřáni $k$ 85. narozeninám pana presidenta republiky T. G. Masaryka, fond Kancelář prezidenta republiky, D 3070/20, kart. 108.

56 Hájková, D.: T. G. Masaryk, s. 175-176.

57 Tamtéž, s. 182-188.

58 Kárník, Zdeněk: České země v ére prvni republiky (1918-1938) II. Československo a české země v krizi a v ohrožení (1930-1935). Praha 2002, s. 574.

59 Hájková, D. - Horák, P.: Narozeniny prezidenta, s. 173. 
Ve způsobu sebeprezentace obou státníků bylo možné najít rozdíly. Beneš si ve vnějším projevu zachovával civilní vzhled. Oproti Masarykově atletické postavě v uniformě to byla změna. Zatímco v textech oslovujících T. G. Masaryka se prvnímu prezidentovi tykalo („tatičku“), Edvardu Benešovi se zásadně vykalo („pane prezidente“). Zaběhnutý rit oslav nebyl důvod zásadně měnit. Budovy veřejných institucí musely být ozdobeny státními symboly tak, aby „v každém směru působily $k$ důstojné oslavě narozenin pana presidenta republiky “. ${ }^{60}$ Centrem ceremonií zůstávala Praha, ale hojně se slavilo také v regionech, především pokud se jednalo o významnější výročí. Konaly se slavnostní bohoslužby, besídky, divadelní představení, akademie či nejrůznější typy průvodů. Představitelé samospráv zasílali na Hrad blahopřání. To se týkalo i oblastí jazykově německých.

Dne 28. 5. 1936 se na Masarykově (Strahovském) stadionu uskutečnila přehlídka pražských ozbrojených sil. Přihlíželo jí 150 tisíc diváků a stala se toho roku nejdůležitějším bodem oslav Benešových dvaapadesátin. Prezidentova účast na ní byla rozplánována do posledního detailu. Nic se nesmělo ponechat náhodě, vše mělo na přihlížející působit. Přesně stanoven byl například i odstup prezidentova doprovodu během pohybu na stadionu. ${ }^{61}$

O důležité roli vojska během oslav v roce 1936 svědčí směrnice presidia Ministerstva národní obrany ze dne 14. května 1936. Na všech vojenských budovách měla být v poledne dne 27. 5. 1936 vztyčena vlajka, popřípadě prapor ve státních barvách. Posádky byly povinny kulturně působit ve svých sídelních obcích. Pro veřejnost pořádaly přednášky o Benešově životě, koncerty vojenských kapel či sportovní utkání. Dělostřeleckým útvarům umístěným na zemských velitelstvích náležela povinnost vypálit v den prezidentových narozenin při budíčku 21 dělových ran. Nařízení se týkalo celé republiky s výjimkou Prahy ${ }^{62}$

60 AKPR, Oslava narozenin pana presidenta republiky Dr. Edvarda Beněse dne 28. května, f. KPR, D 5593/36, kart. 360, s. 1-2.

61 Nadšená manifestace pro armádu. Na strahovském cvičišti v Praze 150000 lidí - Vojenské oslavy po celé republice. Národní politika, 29. 5. 1936, s. 1. Kordon vozidel z Pražského hradu dorazil na Masarykův stadion před devátou hodinou ranní. Edvarda Beneše tam za zvuků fanfár z Libuše přivítali nejvyšší představitelé československé armády armádní generálové Jan Syrový a Ludvík Krejčí a velitel francouzské vojenské mise Louis-Eugéne Faucher. Prezident společně s ministrem národní obrany Františkem Machníkem usedli do kočáru a zamířili do útrob stadionu. Armádní elita usedla na koně a prezidentův vůz následovala. Předvoj spřežení tvořil taktéž na koni jedoucí plukovník Kvapil a tři jezdci nesoucí prezidentskou standartu. Z levé strany kočár koňmo doprovázel velitel přehlídky brigádní generál Viest. Nedlouho po vjezdu na stadion konvoj zastavil. Edvard Beneš vystoupil, přijal hlášení velitele přehlídky a vyslechl státní hymnu. Po uskutečnění slavnostní přehlídky nastoupených útvarů a za pozdravů přihlížejícího obecenstva dospěl prezident na čestnou tribunu, kde na něj čekala první dáma a zástupci parlamentu, diplomatického sboru a armády. Vojenské jednotky pozdravil zvoláním: „Pražská posádko, nazdar“! Načež se mu dostalo hromové odpovědi: „Zdar“! Po kratší přestávce usedl na předem připravenou tribunu, kde shlédl slavnostní defilé. Následně vyslechl závěrečné hlášení generála Viesta a za jásotu přihlížejících davů se odebral zpět na Hrad. Oficiální program přehlídky přesně definoval vhodný „dress code.“ Civilní osoby (muži) v lóži měly být oblečeny v žaketu a nezbytný byl cylindr. Součástí úboru vojenského doprovodu prezidenta musel být kožený řemen se šavlí, hnědé rukavice a za žádoucí se považovalo míti na uniformě připnutá československá vojenská vyznamenání. Srov. AKPR, Program cesty pana presidenta republiky k slavnostni přehlídce pražské posádky na Masarykově stadioně dne 28. května 1936, f. KPR, D 6313/36, kart. č. 360, s. 1-3.

62 AKPR, Vojenská oslava narozenin p. presidenta republiky v r. 1936, f. KPR, D 5726/36, kart. 360, s. 1-2. Pražská posádka byla nastoupená k přehlídce na Masarykově stadionu. 
Apelovalo se také na oficiální účast vyšších úředníků na veřejných slavnostech. ${ }^{63}$ Odlišná situace nastala během oslav ve dvou následujících letech. Vzrostla role dětí. ${ }^{64}$ Kontrolovalo se dokonce, zda v den oslav chodí děti do školy pečlivě umyty a oblečeny. ${ }^{65}$

Oslavy narozenin prezidenta Československé republiky neunikly pozornosti v zahraničí. Vyjma četných poštovních, telegrafických a telefonických pozdravů byly v některých státech pořádány zvláštní akce na jeho počest. Slavilo se v Jugoslávii, Rumunsku, Německu, Řecku nebo francouzských koloniích v Africe. ${ }^{66}$

Občané Československa měli možnost prostřednictvím hradní kanceláře prezidentovi gratulovat. Nejčastěji volili formu zaslání telegramu, pohlednice či dopisu. Ve sděleních byla často vyjadřována sympatie $\mathrm{k}$ prezidentově osobě a sounáležitost se státem. ${ }^{67} \mathrm{Ne}$ lehká pozice Československa v Evropě a instrumentalizace oslav tento jev umocňovala. V roce 1938 se Benešovy narozeniny slavily nedlouho po vyhlášení částečné mobilizace. V témže roce se oslav vůbec poprvé účastnili také komunisté. ${ }^{68}$ Proklamace národní jednoty a odhodlání stát za prezidentem v době ohrožení státu je z dochovaných pramenů patrná. ${ }^{69}$

\section{Prezident „Zachranitel" ${ }^{\mu 70}$ (1939-1944)}

Události konce září roku 1938 znamenaly ostrý předěl ve všech sférách veřejného života. Nicméně, československý stát nadále existoval. S tím i jeho oficiální kalendár. Prezidentské křeslo v listopadu obsadil Emil Hácha. Oslav narozenin se ale v úřadu nejvyššího ústavního činitele nedočkal. Obsazením zbytku území německými vojsky v březnu

63 AKPR, Slavnostni představeni v divadlech na počest narozenin pana presidenta republiky Dr. Beneše, f. KPR, D 5992/36, kart. 360, s. 1-2.

64 Velmi významnou součástí oslav v roce 1938 se stal tzv. Hold školní mládeže presidentu republiky. Uskutečnil se 25. 5. 1938 na Pražském hradě. Zástupy školáků přicestovaly ze všech koutů republiky do Prahy za účelem popřát Edvardu Benešovi mnoho zdraví a sil do dalších snah. Blahopřejné pozdravy byly prosloveny v rodných jazycích jednotlivých deputací - češtině, slovenštině, němčině, rusínštině, mad’arštině, polštině, moravském a slezském nářečí. Srov. AKPR, Projevy děti podle národnosti a zemi, f. KPR, D 8538/38, kart. 360, s. 1-3; AKPR, Odpovédi pana presidenta na pozdravy dětí, f. KPR, D 5631/38, kart. 360, s. 1-2.

65 Hájková, D. - Horák, P.: Narozeniny prezidenta, s. 167.

66 AKPR, f. KPR, H 28/239/35, k. č. 108; AKPR, f. KPR, D 7400/36, k. č. 160; AKPR, f. KPR, D 7250/36, kart. č. 360 .

67 Příkladem sdělení může být telegram Spolku poválečných invalidů z Tatranské Lomnice, kteří si dovolili „vyslovit upřimné práni mnoha dalšich štastných let ve zdravi“ a vyjádřit víru v Benešovy schopnosti „s úspěchem ř́dit osudy naši vlasti“. Srov. AKPR, fond KPR, H 18/42/38, kart. č. 360.

68 Hájková, D. - Horák, P.: Narozeniny prezidenta, s. 174.

69 Hradní kancelář obdržela dne 28. května 1938 telegram z obce Kostelec u Holešova. Tamní obyvatelé v něm prezidentovi děkují „za pevné vedeni naši drahé republiky a slibují brániti tuto v čas potřeby do posledního dechu“. Občané okresu Stará Lubovňa na Slovensku v telegramu ze dne 30. května 1938 projevili prezidentu, „armádě a vládě úplnú oddanost a vernost". Srov. AKPR, f. KPR, H 11/652/38, kart. 360; AKPR, f. KPR, H $11 / 40 / 38$, k. č. 360 .

70 Tento nezvyklý přídomek byl použit v titulu oslavné monografie, která vyšla k příležitosti Háchových sedmdesátin v roce 1942. Jednalo se o parafrázi přízvisek předešlých československých prezidentů. Srov. Tomášek, Dušan - Kvaček, Robert: Causa Emil Hácha. Praha 1995, s. 161. 
následujícího roku a vyhlášením Protektorátu Čechy a Morava v rámci Velkoněmecké ř́̌še se změnila jeho pozice v rámci úřednické hierarchie. ${ }^{71}$ Dne 16. 3. 1939 byl Emil Hácha se souhlasem Adolfa Hitlera jmenován státním prezidentem. Úřad přímo podléhal rozhodnutím ř́šsského protektora. ${ }^{72}$

Okupační správa připomínání narozenin státního prezidenta nebránila. Jak bude níže uvedeno, někdy jich i obratně využívala. Svátek zůstal pravidelným rituálem i v nelehké realitě ročního koloběhu života v protektorátu. ${ }^{73}$ Nicméně, formát oslav se v letech 1939 1945 značně zjednodušil. Okázalé masové ceremonie, známé z období první republiky, nebyly žádoucí. ${ }^{74}$

K příležitosti Háchových narozenin v roce 1939 došlo v jeho rodných Trhových Svinech k odhalení pamětní desky. ${ }^{75}$ Ve stínu čtvrt roku starých událostí se ale nepovažovalo za vhodné ostentativně slavit. Denní tisk přinesl zprávu, že ceremonie proběhly „v Praze na Hradě způsobem prostým a tichým, několika oficiálnimi a soukromými návštěvami “.76

Stejně tak oslavy v letech 1940 a 1941 postrádaly charakter veřejné události. Hácha v Lánech přijímal zástupce vlády a Národního souručenství. Z Prahy mu přijížděl osobně gratulovat řŕšský protektor Konstantin von Neurath. ${ }^{77}$

Obyvatelstvo mělo v letech existence protektorátu jen omezené možnosti, jak se ke gratulacím připojit. Korespondenci prezidentské kanceláře bedlivě kontrolovaly represivní složky. ${ }^{78} \mathrm{~V}$ den narozenin docházelo na Hradě k vyložení gratulačních archů, do nichž se mohli zapsat „osoby oficiálni, zástupci různých korporaci $i$ osoby soukromé “. ${ }^{79}$

Jednou z určujících událostí historické paměti protektorátní společnosti se staly oslavy Háchových sedmdesátin v roce 1942. V porovnání s předcházejícími lety byly pojaty velkolepě. Existovaly k tomu dva důvody. Za prvé, jednalo se o kulatiny. Druhý důvod byl pragmatický. Adolf Hitler chtěl oslav Háchových narozenin využít k utlumení rozhořčených ohlasů veřejnosti ohledně nedávného vypálení Lidic. ${ }^{80}$ Tuzemský i zahraniční tisk zaplnily články o Háchově životě, což byla cílená praktika německé propagandy k vytlačení nežádoucích zpráv o tragickém osudu středočeské obce. ${ }^{81}$

71 Kárník, Zdeněk: České země v ére proni republiky (1918-1938) III. O přežití a život (1936-1938). Praha 2003, s. 619-636.

72 Frajdl, Jiř́i: Protektorát Čechy a Morava. Moravská Třebová 1993, s. 12, 19.

73 Tomášek, D. - Kvaček, R.: Causa, s. 192-193.

74 Hájková, D. - Horák, P.: Narozeniny prezidenta, s. 176.

75 Tamtéź, s. 58-59.

76 V̌̌erejši oslava presidentových narozenin. Národní politika, 13. 7. 1939, s. 2.

77 AKPR, Záznam ze dne 13. črvence 1940, f. KPR, D 2692/40, kart. 190, s. 1-2; AKPR, Záznam ze dne 17. července 1941, f. KPR, D 3104/41, kart. 190, s. 1-2.

78 Tomášek, D. - Kvaček, R.: Causa, s. 58.

79 Členové vlády u státního presidenta v den narozenin. České slovo, 13. 7. 1940.

80 Tomášek, D. Kvaček, R.: Causa, s. 159.

81 Staatspräsident Dr. Hácha 70 Jahre. Der Neue Tag, 11. 7. 1942; Пресидентьть Д-Рь Емиль Хаха Спаситель На Народа. Центропресс Бюулетинь 153, 16. юлий 1942 год.; Staatspräsidenten Dr. Hacha 70 Jahre alt. Völkischer Beobachter, 12. 7. 1942; Glückwünsche des Führers für Dr. Hacha. Deutsche Allgemeine Zeitung, 13. 7. 1942; Dr. Hácha sa dožil 12. júla 70. roku svojho života. Slovenská pravda, 14. 7. 1942, s. 1. 
Ulice Prahy dne 12. července 1942 slavnostně ozdobilo množství praporů a vlajek. ${ }^{82}$ V 10 hodin dorazil státní prezident na Pražský hrad, aby zaujal místo v rámci oficiální části oslav. Těsně po jedenácté hodině přijal nejvýznamnějšího gratulanta - šéfa říšské kanceláře Hanse Lammerse. Společně na třetím nádvoří vykonali přehlídku nastoupených oddílů hradní stráže. Následně Lammers Háchovi osobně pogratuloval a předal mu dar od Vůdce. Tím byla černá limuzína značky Mercedes-Benz. ${ }^{83}$ Hradní kancelář obdržela k př́ležitosti narozenin celou řadu blahopřejných projevů. Úctu vyjádřila také většina říšských politických elit - Hermann Göring, Joachim von Ribbentrop, Joseph Goebbels či Konstantin von Neurath. ${ }^{84}$ Oslavovalo se i mimo Hrad. Narozeniny státního prezidenta si připomínali na úřadech, v závodech a podnicích. ${ }^{85}$

Podobná instrumentalizace oslav, ne však v tak masovém měřítku jako v roce 1942 , probíhala i v ostatních letech fungování protektorátu. Média vykreslovala státního prezidenta nejčastěji jako zachránce národa, jeho jediného „oprávněného mluvčího“ či „prvního občana“. ${ }^{86}$ Zdůrazňována byla Háchova dějinná úloha jakožto muže, který dávno pochopil výhody národního socialismu a fakt, že další existence českého národa je možná pouze po boku národa německého. ${ }^{87}$

Roky 1943 a 1944 byly protkány obavou o prezidentovo zdraví. Vlivem stupňující se arteriosklerózy se prezidentův stav rychle zhoršoval. Zatímco v roce 1943 se programu oslav na Hradě ještě zúčastnil, o rok poději již nikoliv. ${ }^{88}$ Je otázkou, nakolik ještě vnímal projevy úcty. Narozenin v roce 1945 se Emil Hácha nedožil. ${ }^{89}$

\section{Tretí republika (1945-1948)}

Koncepce poválečného Československa se opírala o princip kontinuity. Zejména v právní oblasti se uplatňovala zásada, že uznáním londýnské exilové a následně košické vlády nepřestal nezávislý československý stát nikdy existovat. Za platnou se považovala ústava

82 Vyvrcholeni oslav narozenin pana stát. presidenta. Pražský večer, 13. 7. 1942, s. 2

83 Důkazy úcty a lásky, jež obdržel státní president k 70. narozeninám. Lidové noviny, 15. 8. 1942. Kromě vozidla obdržel státní prezident také bustu Adolfa Hitlera nebo umělecky zpracovaný nábytek. Srov. Exposice darů k narozeninám státního presidenta dr. Háchy. Národní politika, 15. 7. 1942.

84 AKPR, Dopis kanceláře státního presidenta vrchnímu radovi Melčovi, f. KPR, P 1603/42, kart. č. 190. Vůdcovy gratulace tlumočil Hans Lammers. Srov. Glückwünsche des Fuhrers zum 70. Geburtstag Dr. Hachas. Der Angriff, 14. 7. 1942.

85 Vyurcholeni oslav narozenin pana stát. presidenta. Pražský večer, 13. 7. 1942, s. 2.

86 Dr. Emil Hácha - jediný oprávněný mluvč̌ českého národa. Český deník, 12. 7. 1941; Narozeniny proního z nás. Národní střed, 12. 7. 1941; Zachránce českého lidu. K sedmdesátým narozeninám státního presidenta dr. Emila Háchy. Národní práce, 12. 7. 1942; Služba národu, jež oceni historie. Venkov, 11. 7. 1943; Dr. Emil Hácha zachránce národa. Moravské noviny 11. 7. 1944. Je zajímavé, že některé články se Háchovi snaží přisoudit také přízvisko prezidenta „Budovatele“. To byl přídomek do té doby určený výlučně Edvardu Benešovi. Srov. President budovatel. Národní práce, 12. 7. 1942. Autorem citovaného článku byl Emanuel Moravec.

87 Jak oceňoval dr. Emil Hácha národni socialismus již v roce 1934. Národní práce, 12. 7. 1942; Nesmíme se zpronevěrit! Český dělník, 11. 7. 1944.

88 Tomášek, D. - Kvaček, R.: Causa, s. 193.

89 Tamtéž, s. 212. 
z roku 1920 i Zákon o svátcích a památných dnech z roku 1925. Zosobněním kontinuity byl Edvard Beneš. ${ }^{90}$

První oslavy Benešových narozenin proběhly již v roce 1945, nedlouho po prezidentově návratu do vlasti. Slavilo se doma i v cizině. ${ }^{91}$ Především v zemích náležících do britské sféry vlivu nebyly jeho narozeniny v roce 1945 opomenuty. Nepochybně k tomu přispěl fakt, že připadaly na datum jen několik týdnů po oficiálním ukončení druhé světové války v Evropě. Veřejně se oslavovalo v Jeruzalémě či Kapském Městě. ${ }^{92} \mathrm{~V}$ Praze na Hradě došlo k vyložení gratulačních archů. Do nich se zapsalo celkem 4250 osob. To představovalo výrazný nárůst oproti desítkám podpisů v období protektorátu. ${ }^{93}$

V letech 1946 a 1947 proběhly oslavy narozenin prezidenta republiky podle prvorepublikového formátu. Města byla slavnostně vyzdobena, konaly se přednášky, besídky a akademie. Divadla a filharmonie zařazovaly do svých programů speciální vystoupení. Prezident v rámci oficiálního programu provedl na hradním nádvoří přehlídku nastoupených oddílů vojska a přijímal audience vybraných zástupců veřejnosti. ${ }^{94}$ Předstoupil rovněž před vybrané skupiny pražského žactva, které jej v den jeho narozenin přišlo pozdravit. ${ }^{95}$

Zcela jiná situace nastala v roce 1948. Únorová vnitropolitická krize a dramaticky se zhoršující prezidentův zdravotní stav dávaly tušit, že narozeniny toho roku by mohly být Benešovými posledními. Od počátku května trávil většinu času ve vile v Sezimově Ústí. ${ }^{96}$ Blahopřání přijatá hradní kanceláří byla protkána obavami o prezidentovo zdraví. Dopisů došlo několikanásobně více než v letech předchozích. ${ }^{97}$

Drtivá většina pisatelů dávala $\mathrm{v}$ dopisech jasně najevo, že k osobě Edvarda Beneše chovala velmi vřelý vztah. Tím se potvrzují závěry historika Karla Kaplana: Edvard Beneš byl pro většinu obyvatel poválečného Československa symbolem. Zůstal jím po odchodu z funkce v červnu 1948 i po své smrti v září téhož roku. ${ }^{98}$

90 Pehr, M.: Zápas, s. 141, 217.

91 Dr. Benes. The Guardian, 31. 5. 1945.

92 AKPR, Oslavy osvobození republiky a narozenin presidenta, f. KPR, D 08171/45, kart. 360; Dr. Benes'Birthday To-day, Cape Times, 28. 5. 1945.

93 AKPR, Záznam ze dne 31. května 1945, f. KPR, D 1287/45, kart. 360.

94 Oslavy narozenin dr. Beněse. Národ vzdává úctu pronímu občanu. Svobodné noviny, 29. 5. 1946.

95 AKPR, Proslov E. Beneše mládeži ze dne 28. 5. 1946, f. KPR, D 10936/46, kart. 360. Z úryvku Benešova proslovu je patrná dobová atmosféra: „Mladi moji prátelé, děkuji Vám srdečně za to, že jste dnes ke mně přišli na Hrad. Velmi rád Vás tu vidím a vedle diků tedy Vám řeknu pár slov. Prožili jste všichni nejhroznějši válku, jaké ještě v dějinách nebylo. Poznali jste krutost Němců, ale viděli jste také a poznali nezlomnou odolnost a hrdinnost svých otců, matek, bratři $i$ sester. Necht'Vám to nikdy nevymizi z paměti! Bud'te hrdi na svůj národ, nikdy se mu nezpronevěrte, bojujte za jeho svobodu a pracujte pro něj. “

96 Kaplan, Karel: Posledni rok prezidenta. Praha 1993, s. 104.

97 Jako př́ílad může sloužit psaní vrchního strážmistra SNB v Bojkovicích Rudolfa Fialy. Ten přál Benešovi, aby „ještě dlouhá léta ř́dil lodičku naši milované republiky, která toho tak nutně potřebuje“. Načež dodal: „Nepsal jsem Vám nikdy, ale dnes musíme všichni. “ Také Karel Podhajský z Prahy Beneše ubezpečil, „že všichni lidé dobré vůle jej skutečně vroucně miluji“. Srov. AKPR, Gratulace jednotlivcü, f. KPR, A 115250/48, kart. č. 361. 


\section{První dělnický prezident (1948-1953)}

Převzetí moci komunistickou stranou v únoru roku 1948 a následný nástup Klementa Gottwalda do prezidentského úřadu ${ }^{99}$ lze v rámci československých dějin v mnoha ohledech vnímat jako důležitý předěl. Hodnoty ve společnosti se polarizovaly. Nástup nové ideologie ale v kontextu oficiálních obřadů zásadní proměnu stávajících poměrů neznamenal. ${ }^{100}$

Podoba oslav Gottwaldových narozenin v letech 1948-1952 akcentovala prvky známé z oslav výročí narození prezidentů předchozích. Pořádaly se školní besídky, místní oslavy, přednášky. Obce udělovaly prezidentovi čestná občanství. Přejmenovávaly se školy, podniky, doly i města. ${ }^{101}$ Vše probíhalo pod dohledem komunistické strany. Její vedení rozhodovalo o organizování oslav i o zhotovení pomníků či desek s prezidentovou podobiznou. ${ }^{102}$

Objevily se i prvky zcela nové. Příkladem může být přijímání závazků. Poplatně k hodnotám doby se jednotlivci i instituce zavazovali k vyšší efektivitě při plnění svého údělu ve společnosti. Podniky slibovaly pro další rok zvýšení produkce, ${ }^{103}$ doly růst objemu těžby, ${ }^{104}$ zemědělská družstva větší sklizně plodin. ${ }^{105}$ Jak uvedlo v roce 1951 Rudé právo: lid slavil vlasteneckou prací. ${ }^{106}$ Závazky přijímali také učitelé a jejich žáci. ${ }^{107}$

99 Týž: Kronika komunistického Československa. Brno 2009, s. 116-120. S příchodem Klementa Gottwalda na Hrad došlo k zavedení tradic dělnického a stranického prezidenta. První vydržela celých 20 let, druhá až do roku 1989. Autor v knize také upozorňuje na fakt, že k volbě Klementa Gottwalda prezidentem nemuselo dojít. Na počátku vlády KSČ se objevily návrhy na zrušení prezidentského úřadu. Nahrazena měla být institucí tzv. „kolektivního prezidenta“. Tím měla být státní rada, společně řešící záležitosti spadající do prezidentských kompetencí. Tento postup nakonec nebyl doporučen sovětskými poradci.

100 To se také projevilo na obsahu různých veřejných sdělení. Rozhlasové pásmo k příležitosti prezidentových narozenin, jehož autorem byl Zdeněk Novák, v roce 1948 hodnotilo nové poměry takto: „Letos poprvé slaví me narozeniny Klementa Gottwalda jako svátek presidenta republiky. Kdykoliv pohlédneme na vlajicí presidentskou vlajku nad Hradčany, vždy znova si uvědomime dosah velkých změn, které prineslo šest únorových dni tohoto roku. Vždy znovu si uvědomíme že na pražský hrad v čele vítězné dělnické tř́dy přišel Klement Gottwald. A jeho cesta, jeho boj a jeho vítězstvi je cestou pracujicího lidu. "Srov. AKPR, Náš president Klement Gottwald, f. KPR, 303538/48, kart. 611.

101 Do roku 1953 získal Klement Gottwald 756 čestných občanství. Jeho jméno neslo 22 škol, nespočet dolů, závodů či ulic. Město Zlín bylo přejmenováno na Gottwaldov.

102 Kaplan, K.: Kronika, s. 132.

103 AKPR, Blahopráni presidentovi K. Gottwaldovi k 53. nar. ze závodů, f. KPR, 114671/54, kart. 612.

104 AKPR, Blahopráni presidentovi K. Gottwaldovi k 52. nar. - závody, doly, f. KPR, 114671/54, kart. 611. Horníci Západočeských uhelných dolů na počest prezidentových narozenin překročili průměrný denní úhrn těžby o více než 200 tun.

105 AKPR, Blahopřáni presidentovi K. Gottwaldovi k 52. nar. - zemědělci, JZD, f. KPR, 114671/54, kart. 611. Rolníci z Prostějova dokončili k příležitosti Gottwaldových narozenin výsev olejnin na celých $176 \%$.

106 Náš lid slavi 55. narozeniny presidenta Klementa Gottwalda vlasteneckou prací. Rudé právo, 23. 11. 1951, s. 1.

107 AKPR, Blahopřáni žactva národnich a středních škol panu presidentovi republiky $k$ 53. narozeninám, f. KPR, 134104/48, kart. 611. Žákyně Margita Bartošová slíbila v listopadu 1949, že se do konce prosince naučí pět ruských písní, zlepší si prospěch a nasbírá 50 kilogramů papíru. 
Na počest narozenin Klementa Gottwalda vycházela řada oslavných textů. Některé měly podobu samostatné publikace, ${ }^{108}$ jiné se objevovaly v novinách ${ }^{109}$ či byly předčítány v rozhlase. ${ }^{110} \mathrm{~V}$ roce 1950 vyšel ke stejné příležitosti první díl Gottwaldových spisů. ${ }^{111}$ Stejně jako celá řada dalších svátků v Československu byla i oslava narozenin prezidenta republiky po roce 1948 instrumentalizována. Strana příležitosti využívala a s pomocí vhodně zvoleného obsahu svátku se zasazovala o další rozšiřování státní ideologie.

Vlastní prezidentův program v den oslav se prakticky nezměnil. Dominovalo v něm přijímání audiencí a různá veřejná vystoupení. Gottwaldovi předchůdci obvykle jako první přijímali diplomatické zástupce z ciziny a až po nich představitele tuzemské politické scény. První komunistický prezident pořadí obrátil, přičemž přední místo v hierarchii oficiálních návštěv zaujali přední funkcionáři KSČ. ${ }^{112}$

Do hradní kanceláře mířilo každoročně několik tisíc blahopřání. Pozdravy zasílaly místní a krajské organizace KSČ, podniky, umělecká tělesa, školy, vojenské oddíly, ale zpočátku také církve či lokální sdružení zemědělců. ${ }^{113}$ Československo oslavilo narozeniny Klementa Gottwalda ve funkci prezidenta republiky celkem pětkrát. Ani jedna z oslav nebyla pro historickou pamět národa zvlášt určující. V období let 1948-1952 hlava státu neslavila kulaté výročí narození, ani se nerozhodovalo o zásadních politických otázkách.

Gottwaldův skon přišel v březnu 1953 poněkud nečekaně. Bezpodmínečná adorace jeho osobnosti byla postupně odsouzena jako kult. V roce 1954 se na schůzích KSČ Gottwaldovy narozeniny ještě připomínaly. Naposledy se veřejně slavily jeho nedožité šedesátiny v roce 1956. Krajská a okresní ústředí KSČ obdržela směrnice, podle nichž měla oslavy v důstojném duchu organizovat. ${ }^{114}$ Ústřední událostí se stal slavnostní vzpomínkový večer v Obecním domě v Praze. Večera se zúčastnili všichni vrcholní funkcionáři KSČ, zástupci veřejného života v Československu a diplomaté spřátelených zemí. Hlavním řečníkem na akci byl člen ústředního výboru KSČ Václav Kopecký. ${ }^{115}$ Od následujícího roku bylo vzpomínání omezeno pouze na sdělení v tisku. ${ }^{116}$

108 Rais, Štefan - Nečásek, František - Pachta, Jan: O presidentu Gottwaldovi. Tři přednášky. Praha 1949.

109 Strůjce historických vítězství našeho lidu. Rudé právo, 23. 11. 1951, s. 1.

110 AKPR, Náš president Klement Gottwald, f. KPR, 134104/48, kart. 611.

111 Spisy Klementa Gottwalda. Rudé právo, 23. 11. 1950, s. 3.

112 AKPR, Narozeniny pana presidenta dne 23. listopadu 1948, f. KPR, 126910/48, kart. 611.

113 AKPR, 52. narozeniny p. presidenta Klementa Gottwalda, seznamy došlých blahopřani, f. KPR, 135.037/48, kart. 611.

114 Památce prvního komunistického prezidenta byla zasvěcena většina úvodní strany Rudého práva: „V celé republice, v krajich a v jednotlivých okresech probihaly vzpominkové večery, slavnostni besedy $k$ 60. výroči narozeni Klementa Gottwalda. “ Pracující v Bratislavě vzdali hold „nesmrtelné památce“ zemřelého vůdce již o den dřive. Srov. Vzpominkové oslavy v celé republice. Rudé právo, 23. 11. 1956, s. 1.

115 V nerozborné jednotě dovršime započaté dílo. Rudé právo, 23. 11. 1956, s. 1. Kopecký ve svém projevu nejednou zdůraznil, že připomenutí Gottwaldových narozenin by v žádném případě nemělo být bráno jako součást jakéhokoliv kultu osobnosti.

116 Kaplan, K.: Kronika, s. 135. 


\section{Závěr}

Oslavy narozenin prezidenta republiky byly v letech 1919-1953 pevnou součástí veřejného prostoru. Původ svátku spadal do dob habsburské monarchie a jeho charakter zůstával polooficiální. Po celé sledované období nedošlo k jeho zařazení do oficiálního svátkového kalendáře státu.

Vnější podoba dne se proměnila jen málo. T. G. Masaryk se po vzniku nezávislého Československa zasadil o převzetí modelu císařských oslav. Ulice měst a obcí v den narozenin zkrášlily vlajky, prapory a další státní symboly. Pořádaly se různé kulturní akce - přednášky, besídky, akademie. Umělecká tělesa zařazovala do programu zvláštní představení. Ústřední roli během oficiálních ceremonií měly děti. Předávaly květiny, pronášely blahopřání. Velmi důležitá byla účast vojska. Vlastní prezidentův program se v den oslav zpravidla skládal z přijímání audiencí, veřejných proslovů či účasti na vojenských přehlídkách.

Za zlatý věk oslav lze označit období první republiky. Ceremonie měly velmi často masový charakter. Tento jev byl ještě více patrný v letech půlkulatých a kulatých narozenin či v období, kdy byla československá státnost ohrožena. Druhá světová válka oslavy zjednodušila a učinila je mnohem méně okázalými. Výjimku tvořil pouze rok 1942, kdy německá propaganda využila oslav sedmdesátin Emila Háchy k utlumení ohlasů na vypálení obce Lidice. V prvních poválečných letech došlo k jisté reminiscenci. Třetí republika jevila snahu o udržení kontinuity s předválečným Československem. Model v podstatě převzal také poúnorový komunistický režim. Obohatil jej však o mnohé nové ideologické prvky. Příkladem může být přijímání závazků podniky, družstvy i školami. Symboly státnosti byly doplněny rudými hvězdami, kladivy a srpy. Vlastenecká hesla nahradily proletářské slogany. Instrumentalizace oslav byla jevem naprosto běžným. Lze konstatovat, že každé z vládnoucích ideologií v průběhu let 1919-1953 sloužily oslavy narozenin prezidenta republiky jako nástroj k upevnění vlastních legitimizačních hodnot.

Úřady ovlivňovaly podobu oslav emisemi publikací obsahujících náměty jednotlivých programů, považovaných pro danou př́ležitost za vhodné. Informace přinášel denní tisk. S postupem času rostl význam rozhlasu.

Z hlediska historické paměti se připomínání dne narození prezidenta stalo důležitým projevem sebeidentifikace jedince s československým státem. Ti, kteří byli přímými aktéry, jeho existenci přijímali, nebo se s ní smíruili. Některé skupiny obyvatel svátek ignorovaly. Objevily se i projevy nesouhlasu. Odmítavé postoje byly typické především v období let 1919-1938. Jejich zastánci pocházeli většinou z prostředí německé nebo mad’arské minority, popř́ípadě z řad komunistické strany.

Oslavy v některých letech byly pro kolektivní pamět československé společnosti mimořádně formující. Z Masarykovské éry do této kategorie spadaly roky 1920 a 1930. Dynamická období prezidentství Edvarda Beneše dala více př́ležitostí k využití svátku jako prostoru pro manifestaci národní sounáležitosti. Symptomatickými se staly oslavy v letech 1936, 1938 a 1948. Také narozeniny Emila Háchy v roce 1942 byly v kontextu protektorátního života výjimečné. Pouze v období úřadování Klementa Gottwalda nelze, 
z hlediska historické paměti, označit žádnou z oslav za zásadní. Na druhou stranu, komunistický režim obohatil ceremonie novými, zcela svébytnými obsahy.

Předložený př́spěvek si kladl za cíl poukázat na to, jak se oslavy prezidentských narozenin v průběhu let 1920-1953 změnily. Z uvedeného je zřejmé, že jejich vněǰš́ forma zůstávala prakticky stejná. V závislosti na politických okolnostech, náladě ve společnosti a státní ideologii se však zásadně odlišovaly svým obsahem a instrumentalizačním záměrem.

\section{"Happy Birthday, Mr. President!" A Reflection of the President's Birthday Celebrations in 1919-1953 (on the Example of the Official Documents of the Office of the President of the Republic)}

The presented study is trying to analyze the development of the image of the Czechoslovak president's birthday celebrations in 1919-1953. Based on the tradition of emperor's birthday celebrations of the Austrian-Hungarian monarchy the feast became one of the most defining rituals of this era. Although it never became an official part of the valid law, the annual celebrations lasted until the revision of the cults of personalities of Joseph Stalin and Klement Gottwald in 1950's, Afterwards, the feast as a massive ceremony disappeared from the Czechoslovak public space.

The article takes a look into the described topic by using the Maurice Halbwachs' sociologist theory of the collective memory which was originally published in 1929. By examining the official documents of the Czechoslovak executive power and the Office of the President of the Republic the text reveals how the feast was instrumentalized during the terms of the first four presidents of the independent Czechoslovakia. It is also trying to explain and describe which tactics were used to get the desired results. Those ways differed according to the ruling ideology and the personality of the president.

The work is a contribution to the research of the Czechoslovak society in the first half of the $20^{\text {th }}$ century. It should help to understand more about the history of feasts, which influenced the forming of our current national values and narration of the past. 